\title{
Characterization of Ilmenite from Kerala Coastline, India: Implications in the Production of Synthetic Rutile
}

\section{Sundararajan*, K.H. Bhat, S. Velusamy, N. Babu, M.E.K. Janaki, S. Sasibhooshanan, and P.N. Mohan Das}

National Institute for Interdisciplinary Science and Technology, formerly Regional Research Laboratory, Council of Scientific and Industrial Research, Thiruvananthapuram - 695019, India

*Corresponding Author: rajanmsundar77@yahoo.com, rajanmsundar77@rediffmail.com

Phone: 0091-471-2515285 / 2515250, Fax: 0091-471-2491712

\begin{abstract}
Surface samples have been collected from Kerala coast, Chavakad - Ponnani (CP- central sector), Neendakara - Kayamkulam (NK- southern sector) beach sectors for ilmenite characterization studies. The $\mathrm{TiO}_{2}$ percentage in samples from $\mathrm{NK}$ deposit is greater than that in CP deposit. X-ray diffraction analysis of ilmenite shows characteristic peaks of ilmenite and some altered phases, such as pseudorutile, pseudobrookite, etc. Two ilmenite samples separated from CP and NK deposits were subjected to chemical beneficiation for production of synthetic rutile by a process developed and patented by NIIST. Investigations revealed that ilmenite samples with $32.95 \%$ and $56 \% \mathrm{TiO}_{2}$ could be upgraded to synthetic rutile of $95 \% \mathrm{TiO}_{2}$ content. However, economic viability of upgrading lean ore to synthetic rutile is largely dependent on commercial utilization of large quantities of iron oxide produced as the by product.
\end{abstract}

KEY WORDS: Ilmenite characterization, synthetic rutile, XRD, SEM, Kerala coast.

\section{INTRODUCTION}

Indian beach placers are significantly different from other continental placer deposits in every geological and mineralogical sense. They are different in terms of total and individual mineral reserves, degree of weathering/alteration in placer constituents, mineral paragenesis and evolution of deposits. The heterogeneity is further displayed in the form of complex trace 
element composition, crystal structure, variation in physical properties and micromorphology of grains. This necessitates formulating locally acceptable options for value-based exploitation on the basis of three-dimensional pattern and geometry of placers and systematic mineralogical characterization of black sands, which is followed by specific processing stages. Ilmenite forms the largest constituent of Indian beach sand deposits ( 348MT), followed by Sillimanite $(\sim 120 \mathrm{MT})$ and Garnet ( 107MT). Zircon is only 21MT and Rutile 18MT [1]. This study also deals with the alteration phases and major mineral chemistry for the monominerallic minerals (ilmenite) through XRD, SEM, and wet chemical analysis of samples of beach sediments of northern, central, and southern region of Kerala and South coast of Karnataka coast. The chemical beneficiation of ilmenite from Chavakkad- Ponnani and Neendakara - Kayamkulam areas of Kerala coast to high-grade synthetic rutile was also studied.

\section{STUDY AREA}

The heavy mineral occurrence of Chavakkad - Ponnani extends along a coastal stretch of $18 \mathrm{~km}$ over an area of $4.71 \mathrm{sq} \mathrm{km}$ south of Ponnani river mouth in the Malappuram and Thirssur districts [2]. Neendakara-Kayamkulam placer deposit in the Kollam district, commonly known as Chavera deposit, covers a total coastal length of $22.54 \mathrm{~km} \mathrm{[3-6].} \mathrm{The} \mathrm{deposit} \mathrm{is} \mathrm{located} \mathrm{along} \mathrm{a}$ barrier beach with an average width of about $200 \mathrm{~m}$ between the two tidal channels, at Neendakara in the south and Kayamkulam in the north (Figure 1).

\subsection{Geology Setting of Kerala}

The coastal land consists of crystalline rocks of Archaen age, sediments of tertiary age, and laterite capping on crystalline and sediments of sub-recent to recent age. The crystallines include charnockites and Khondalites, granite gneisses and granites traversed by basic rocks. Charnockite is wide spread in the hill ranges of Western Ghats. Hornblende and biotite gneiss occur locally and are derived by retrograde metamorphism and migmatisation of biotite gneiss. Khondalitic rocks are exposed in the south kerala and Palghat districts. Quartz and pegmatite veins are intrusive into charnockites and schists. Dolerite, basalt and gabbro cut across the crystalline rocks variegated sandstones and clays of Miocene age with lignite grains overline the compact sands and clays with shell fragments. Laterite is the product of residual chemical weathering of the crystalline rocks and tertiary sediments and forms flat-topped hills and ridges between the foothills of the western ghat and the Arabian Sea. 


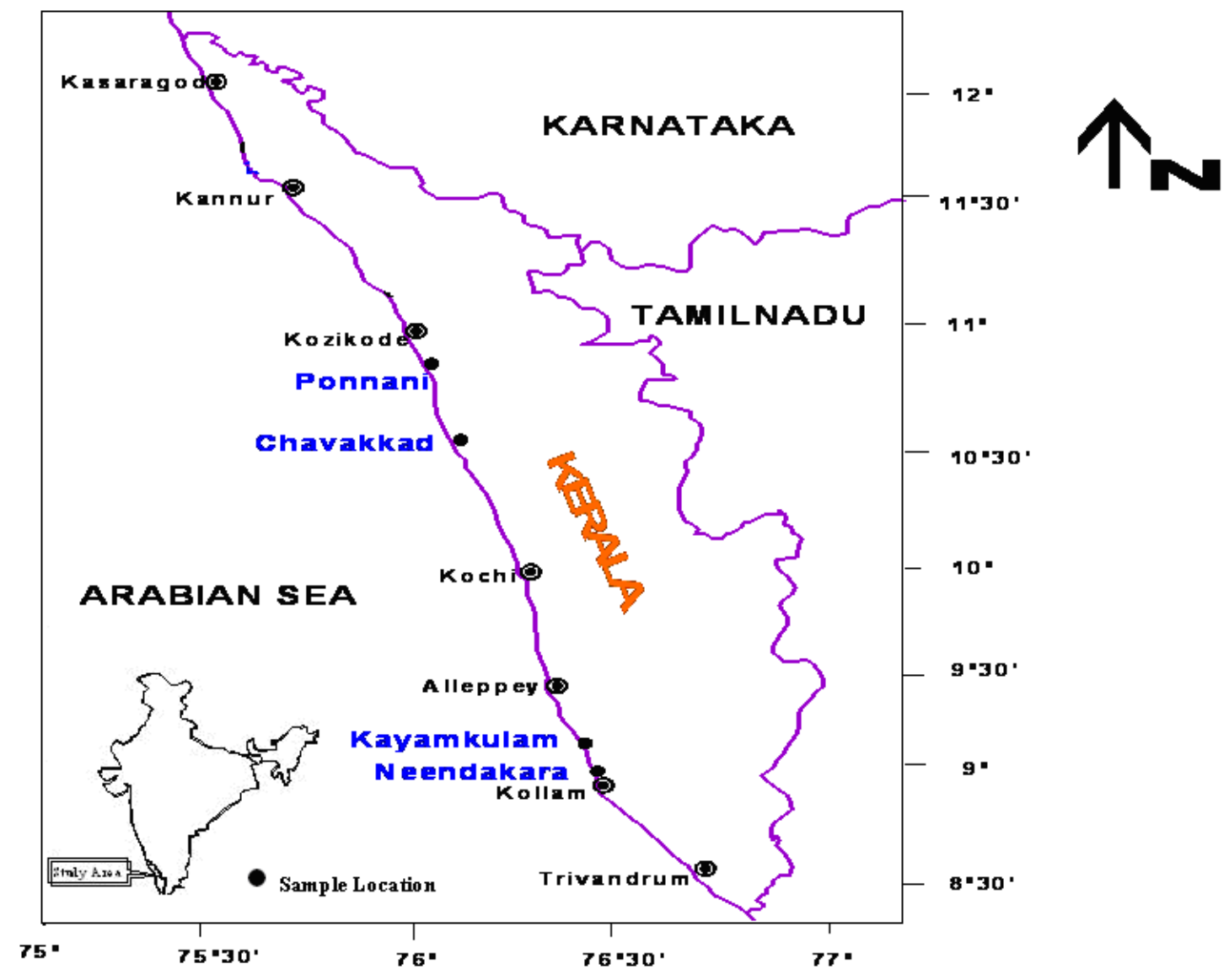

Figure 1. Location map and sampling station

\subsection{Geomorphologic Setting}

The coastline of Kerala is, very dynamic and fluctuates seasonally [7]. On closer observation, it can be seen that the coastline is highly irregular, cliffed and wave-eroded of its total length of $560 \mathrm{~km}$. Seasonal fluctuations and dynamic variations are prevalent over a length of $360 \mathrm{~km}$. The beaches of kerala are narrow with width less than 500m except the sector between north of Karunagapally (in Southern Kerala) and Ponnani. Coastal features like cliffs, stacks, shore platforms, spits, bars and beach ridges are developed at several places along the coast of Kerala [7].

Some of the heavy mineral concentration like at Valapatanam - Azhikode, Chavakkad - Ponnani are found to extend southwards from the mouth of major rivers [8]. This may be due to the combined sorting action of the high-energy waves and long shore currents during monsoon period. The occurrences of pure quartz sands at Cherthala, and high concentration of heavy 
minerals at Neendakara - Kayamkulam area are linked to relative sorting and transport of light minerals by the north flowing long shore currents [8].

\section{MATERIALS AND METHODS}

\subsection{Chemical Characterization}

Powdered ilmenite was brought into solution by fusion with $\mathrm{KHSO}_{4}$ and dissolution in hot dilute $\mathrm{H}_{2} \mathrm{SO}_{4}$. Titanium was determined by reducing titanium IV to titanium III using aluminum metal and titrating with standard ferric ammonium sulphate [9]. The total iron is estimated by stannous chloride reduction $-\mathrm{K}_{2} \mathrm{Cr}_{2} \mathrm{O}_{7}$ titration method. The content of $\mathrm{FeO}$ in the ilmenite is analysed by treating the powdered ilmenite with $\mathrm{HF}-\mathrm{H}_{2} \mathrm{SO}_{4}$ mixture and titrating with Standard $\mathrm{K}_{2} \mathrm{Cr}_{2} \mathrm{O}_{7}[10]$.

\subsection{Physical Characterization}

Representative samples of minerals were powdered to 200 mesh for X-ray diffraction studies so as to understand the homogeneity of the substances following the procedure [11]. The scan rate was kept for $2^{\circ}$ per minute and the spectrum range was maintained between 10 and $50^{\circ}$ for $2 \Theta$. Cathode tube was used for irradiation. The representative samples of ilmenite grain were studied under Scanning electron microscope - Joel JSM-5800. The grains were mounted on the brass stud. The mounted ilmenite grains were coated with gold in a vacuum evaporator while the sample was being slowly rotated typical micrographs were taken.

\subsection{Beneficiation of Ilmenite Samples}

Two mineral samples collected from Chavakkad - Ponnani and Neendakara- Kayamkulam areas of Kerala coast were used for beneficiation studies. Upgradation of these samples to synthetic rutile was carried out at NIIST- Trivandrum by a process developed and patented by the Institute [12]. The details of the preparation of synthetic rutile from ilmenite mineral samples are given below:

\subsubsection{Metallization of ilmenite}

Reduction experiments were carried out in batch tubular reactors, heated externally by a muffle furnace. The reduction parameters such as reduction temperature, residence time and ilmenite /coal ratio were fixed at $1050^{\circ} \mathrm{C}, 4$ hours and $1: 1$ (W/W) respectively for metallization experiments [12]. 


\subsubsection{Oxidative removal of metallic iron from reduced ilmenite}

Rusting experiments were carried out in a $2000 \mathrm{ml}$ PVC beaker fitted with baffles, air distribution tube and a mechanical stirrer. Metallised ilmenite was suspended in an aqueous medium of about 2.5 times the weight of the solid containing $1.5 \%(\mathrm{w} / \mathrm{v})$ ammonium chloride and the initial $\mathrm{pH}$ of the solution was adjusted to 4 by the addition of acid. Compressed air at the rate of 4-5 liters/minute was continuously purged to the solution while a mechanical stirrer kept the solids in suspension. After rusting, the beneficiated ilmenite and hydrated iron oxide were separated by dilution and decantation, washing repeatedly, until the solid product is free from iron oxide. The solid product after acetone rinsing was subsequently dried.

\subsubsection{Rutilation of beneficiated ilmenite}

Reoxidation studies were carried out in presence of air in a muffle furnace. Rusted ilmenite spread in a thin layer in an alumina dish was subjected to reoxidation in the temperature range of $700-800^{\circ} \mathrm{C}$ for a residence time of 1 hour.

\subsubsection{Acid leaching of reoxidised product}

Leaching experiments were carried out in a $500 \mathrm{ml} 3$-necked rounded bottom flask. The solid was continuously stirred at regulated speed using a magnetic stirrer. The flask containing the solution was heated externally by means of an oil bath and the temperature of the solution was regulated and kept at desired constant level using energy regulator. Keeping in view, the generation of excessive $\mathrm{HCl}$ fumes very close to the boiling point of $20 \% \mathrm{HCl}$, a temperature of $\left(80-90^{\circ} \mathrm{C}\right)$ was adopted during leaching, though higher temperature yielded better iron removal. Solid/liquid ratio of 1:5 (w/v) was found to be optimum for the desired rate of mass transfer. Leaching experiments were carried out at $90^{\circ} \mathrm{C}$ with $20 \% \mathrm{HCl}$ for $6-8$ hours

\section{RESULTS AND DISCUSSION}

\subsection{Characterization of Ilmenite}

The $\mathrm{TiO}_{2}$ content of the ilmenite of central deposit is $34.30 \%$ and of southern deposit is $60.54 \%$. The $\mathrm{TiO}_{2}$ content of southern deposit is higher than any other known deposits of the world. The $\mathrm{FeO}$ content in these deposits are $23.76 \%$ and $10.81 \%$, respectively for central and southern deposit. $\mathrm{Fe}_{2} \mathrm{O}_{3}$ in central area shows $22.81 \%$ whereas southern sector shows $25.04 \%$. The higher percentage of $\mathrm{Fe}_{2} \mathrm{O}_{3}$ over $\mathrm{FeO}$ is characteristic of the southern deposit and it has been found that weathering and subsequent leaching processes play a vital role in improving the grade of 
ilmenite (Table 1). Even though Brazilian ilmenite is more weathered than the Indian ilmenite, its $\mathrm{TiO}_{2}$ content is low due to lesser removal of ferric oxide by leaching [8].

Table 1. Chemical analysis and alteration stages of ilmenite from beach sand of Kerala.

\begin{tabular}{|c|c|c|c|c|c|c|}
\hline Sample & $\mathbf{F e O}$ & $\mathbf{F e}_{\mathbf{2}} \mathbf{O}_{\mathbf{3}}$ & Total Iron & $\mathbf{T i O}_{\mathbf{2}}$ & $\mathbf{T i} / \mathbf{T i}+\mathbf{F e}$ & Alteration stage \\
\hline (CP- central sector) & 26.75 & 28.48 & 40.71 & 37.28 & 0.35 & Ferrian Ilmenite \\
\hline (NK- southern sector) & 10.65 & 25.15 & 25.87 & 60.71 & 0.58 & Hydrated Ilmenite \\
\hline
\end{tabular}

Ilmenite from southern sector shows a higher content of $\mathrm{TiO}_{2}$ of the order of $60.71 \%$ with iron content around $25.87 \%$, whereas the ilmenite from central sector contains $40.71 \% \mathrm{TiO}_{2}$ and $37.28 \%$ total iron.

The chemistry of iron and titanium in the ilmenite mineral structure is the most evident and direct indicator of the stage of alteration undergone. While the oxidation stage of iron is defined by the ferrous-ferric conversion, as the first stage of alteration, the latter process is a function of leaching of iron from the mineral structure and the corresponding enrichment of titanium. Thus the study of major elements of ilmenite has implications in the assessment of the quality of ilmenite ore.

Different elemental ratios have been proposed to delineate the weathering mechanisms in ilmenite. Forst [13] has classified ilmenite alteration into four stages based on the $\mathrm{Ti} /(\mathrm{Ti}+\mathrm{Fe})$ ratios. The terminology of those stages in the order of increasing stage of alteration is as follows. The $\mathrm{Ti} /(\mathrm{Ti}+\mathrm{Fe})$ values for different stages of alteration are as follows Ferrian Ilmenite $(<0.5)$, Hydrated Ilmenite $(0.5-0.6)$, Pseudorutile $(0.6-0.7)$ and Leucoxene $(>0.7)$. This system has been adopted and has been used in this work for the chemical characterization of ilmenite based on the major element chemistry.

The chemical analysis carried out for this investigation, is detailed as Ferrian ilmenite 0.35 in central sector, and hydrated ilmenite 0.58 in southern sector (Table 1). It was observed that the ilmenite exhibited different stages of alteration at different locations.

\subsection{X-ray Diffraction Analysis}

X-ray diffraction pattern of ilmenite of the central sector reveals the presence of ilmenite and pseudorutile but the ilmenite of southern sector comprised of pseudorutile, and pseudobrookite phases also along with ilmenite. (Fig 2 a \& b). 


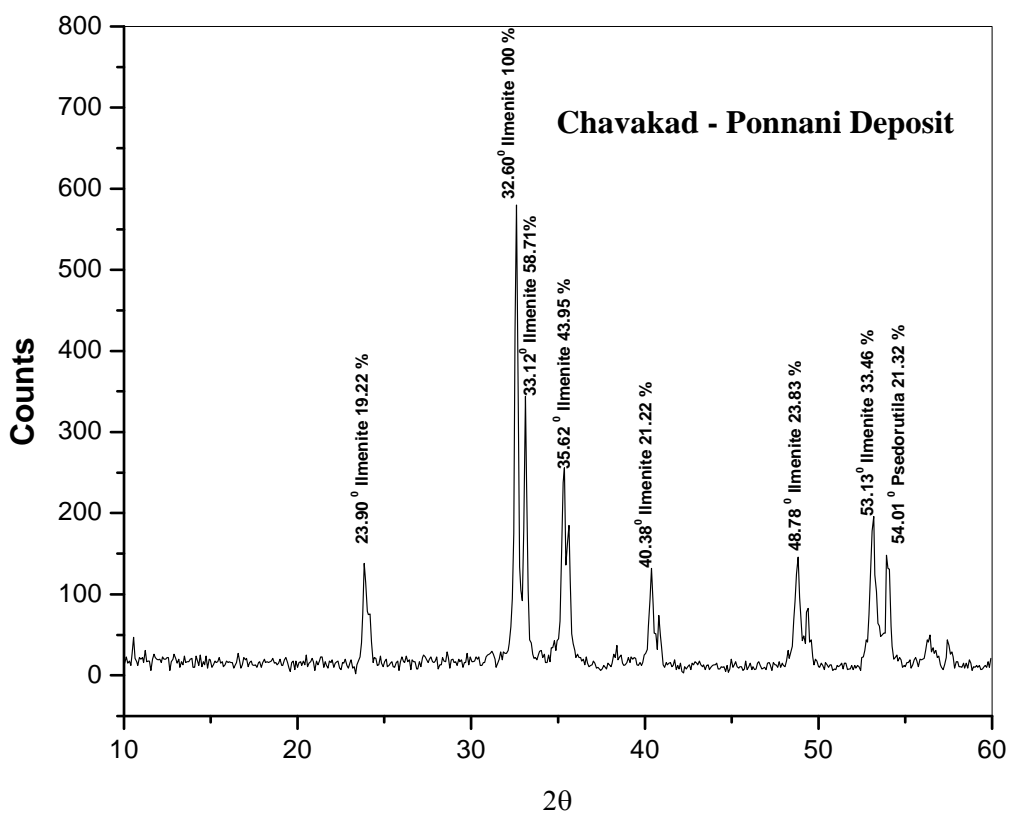

(a)

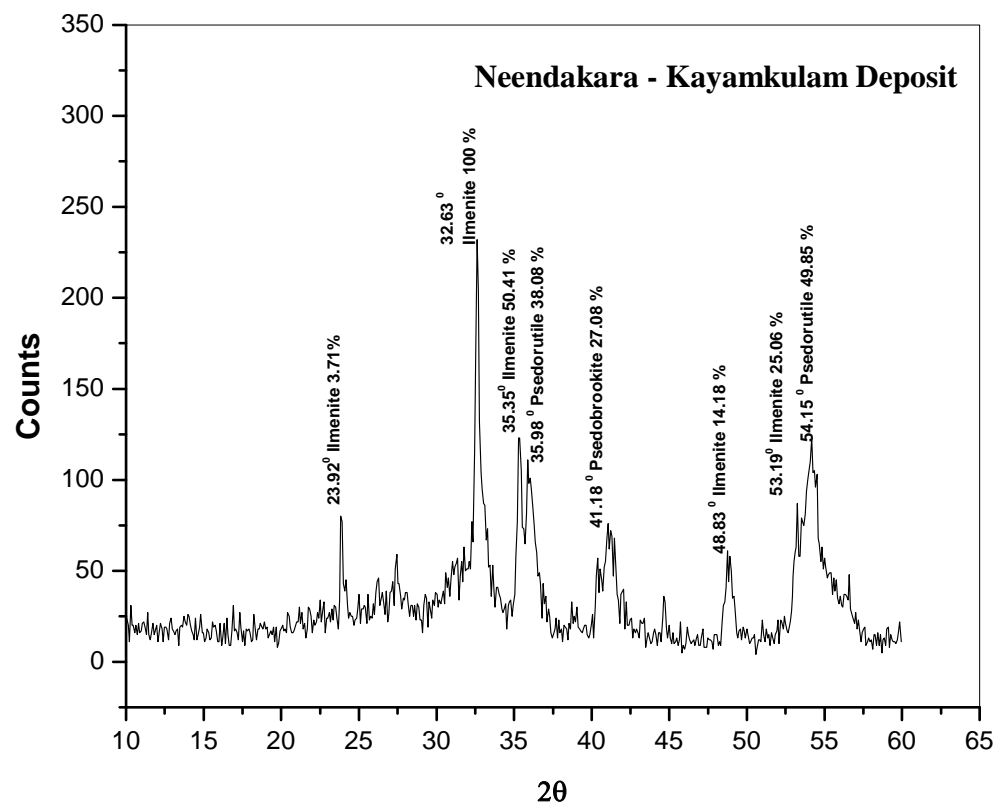

(b)

Fig. 2 X-Ray diffractrograms of representative ilmenite from central and south sectors. 


\subsection{Scanning Electron Microscopic Investigations}

Micro morphological studies of ilmenite from the two sectors (Fig.3) using SEM reveal different features. Presence of opaque in relatively higher proportions in the two sectors as well in all size fractions shows that they are being derived from the Crystallines and Khondalites of the Western Ghats by Mahe, Periyar, Bharathapuzha, Kallada and Manimala rivers.

Mallik [14] have stated that Charnockites and retrograde charnockites are the sources for hypersthene and hornblende respectively for the opaque minerals of the Central Kerala whereas opaques of fine sand fraction in central sector i.e. Chavakad-Ponnani are less, due to excess depositions of flaky minerals i.e., amphibole, biotite, chlorite, pyroxene and minerals like garnet and zircon by Chetuva puzha as well as of Bharathapuzha rivers. Minerals like amphibole, biotite, chlorite, and pyroxene's are found absent in the southern sector of Kerala region which strongly supports the paragenesis, i.e., Khondalites of southern region are devoid of the above said heavy minerals. Zircon is especially concentrated in the very fine sand fraction. Zircon, especially the pink variety, though small in their content, shows variety of inclusions. Euhedral zircons have typical zoning characteristics, fracture lines and dust inclusion suggesting the possibility of their derivation from the granites and gneisses ${ }^{[15]}$.

Garnet is present in moderate proportion in the central sector due to the selective transportation and deposition by the southerly directional coastal currents. The garnets would have derived from the adjacent garnet-hypersthene-epidote-sillimanite provenance of Bharathapuzha river [14] .The relatively limited alteration of ilmenite in the central sector is attributed to its occurrence in active, high energy depositional environment, where only the non stable minerals remain preferred and digenetic process is absent.

These features are described by mechanical and chemical processes. Ilmenite grains from the central sectors are sub-rounded in shape (Fig 3a). Presence of micro cavity (Fig 3b) and over growth (Fig 3c) may be due to mechanical and chemical solution activities. Ilmenite grains of southern sectors are sub rounded in shape (Fig 3d). Mechanical hit fractured features are also observed in the ilmenite of southern sector (Fig g). Compared to the central sector, these grains are chemically more altered. Hence the ilmenite of southern sector exemplifies very high degree of alteration than the central sectors (Fig e, f, h). XRD and chemical analysis also support the above observations. 


\section{SEM of Central sector}

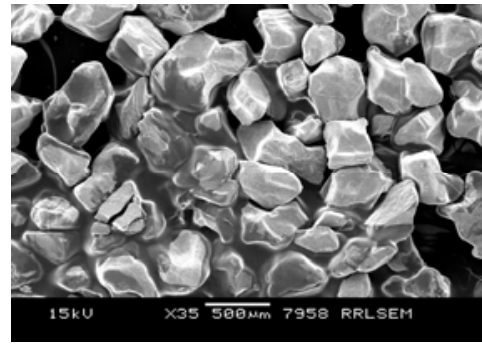

Fig (a) Grain showing rounded

\section{SEM of ilmenite from the southern sector}

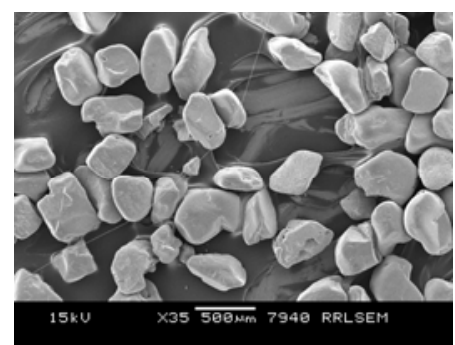

Fig (d) sub rounded grains Ilmenite

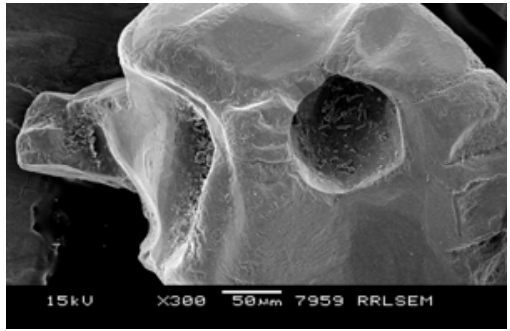

Fig (b) Micro cavity present

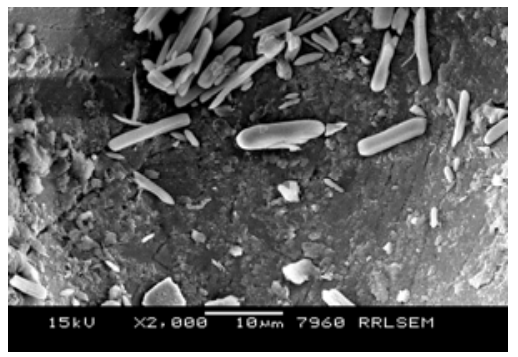

Fig (c) Grain showing sub over growth

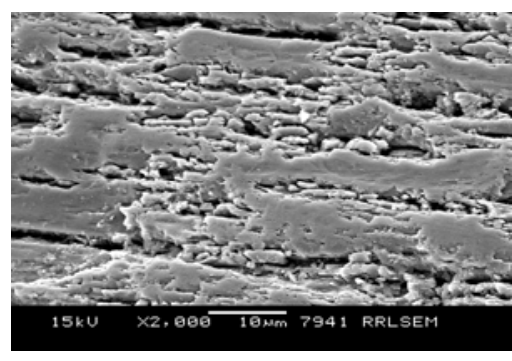

Fig (e) Grain showing process of lecoxenisation

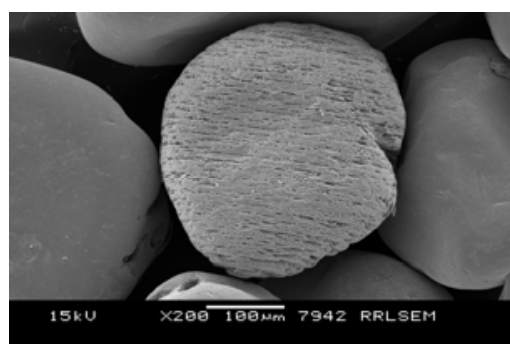

Fig (f) Weathered Ilmenite

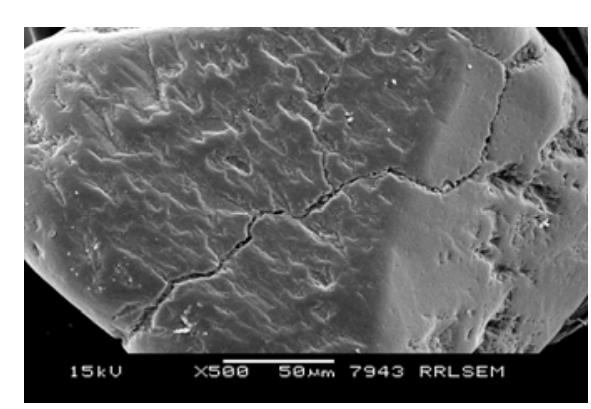

Fig (g) Fractured ilmenite

Fig. 3. SEM of ilmenite from central and southern sector Kerala coast.

\subsection{Chemical Beneficiation}

Metallised ilmenite with about $85 \%$ metallization was obtained from the samples of both the sector. Formation of substantially porous and highly reactive layer of metallic iron at the surface of ilmenite grain during the reduction was made use of in its effective separation and removal 
from ilmenite. A product containing about $84-86 \% \mathrm{TiO}_{2}$ and 6-7\% residual iron was obtained after rusting.

Beneficiated ilmenite after rusting contained still about $6-7 \%$ residual iron in the metallic and ferrous state. This residual iron was observed to be well within the ilmenite grain and as such not amenable for removal during acid leaching. Reoxidation of this product was found to have the following advantages:

1. Reoxidation of ferrous and metallic iron effect cracking and formation of voids in the ilmenite grain, which rendered faster and maximum removal of iron during leaching.

2. Oxidation of iron was also found to cause outward migration of iron values on to the grain surface.

3. Reoxidation at $700-800^{\circ} \mathrm{C}$ also removes organic contaminants associated with the reduced ilmenite.

4. Removal of iron in ferric state during leaching renders recovery of iron values from the leach liquor easy without any pretreatment.

5. Reoxidation of beneficiated ilmenite prior to leaching results in golden brownish colored high grade synthetic rutile compared to black product obtained in the Becher process.

Reoxidation temperature and residence time were however found to be important parameters affecting the leachability of the product.

The residual iron associated with the ilmenite after rusting was finally removed by acid leaching of the oxidized product. Though the degree of iron removal increased with the acid concentration, only $20 \% \mathrm{HCl}$ was used in leaching as it forms a mixture very close to azeotropic composition.

The leaching process resulted in a product of synthetic rutile containing more than $94 \% \mathrm{TiO}_{2}$ and $3 \%$ Iron. The value addition of ilmenite mineral samples in terms of $\mathrm{TiO}_{2}$ content brought about by chemical beneficiation is given in the Table 2 .

Table 2. The value addition of ilmenite mineral samples

\begin{tabular}{|c|l|l|}
\hline Sample & Initial $\mathbf{T i O}_{\mathbf{2}}$ Content & $\mathbf{\%} \mathbf{~ T i O}_{\mathbf{2}}$ \\
\hline (CP- central sector) & $32.95 \%$ & 95.07 \\
\hline (NK- southern sector) & $56.05 \%$ & 94.20 \\
\hline
\end{tabular}

The above investigations clearly reveal that the sample containing only $32.95 \% \mathrm{TiO}_{2}$ content when subjected to chemical beneficiation resulted in a synthetic rutile product containing 95.07\% $\mathrm{TIO}_{2}$ compared to sample containing initial $\mathrm{TiO}_{2}$ content of $56.05 \%$ which has yielded a 
product of only $94.20 \% \mathrm{TiO}_{2}$. It was observed that the quality of the final product of synthetic rutile in terms of $\mathrm{TiO}_{2}$ content produced from ilmenite minerals is independent of the initial $\mathrm{TiO}_{2}$ content of the mineral.

\section{CONCLUSIONS}

The chemical analysis of fractionated samples of southern and central sector indicates that the composition of the mineral varies with in the deposit along the length of beach. It is also observed that the ilmenite samples of southern area contain more than $60 \%$ of $\mathrm{TiO}_{2}$ where as those from central sector are very poor $\mathrm{inTiO}_{2}$ content. Wet chemical studies reveal that the samples from the southern sector are more altered than that from central sector. X-ray diffraction pattern shows some altered phases of mineral such as pseudorutile, pseudobrookite. Very minor peaks of hematite also are seen in some cases. SEM studies also support very high alteration characterization in ilmenite from southern sectors.

The ore being rich in $\mathrm{TiO}_{2}$ content and comparable to the established commercial grades, the economy of the chemical beneficiation to high-grade synthetic rutile is highly promising. It was observed that the quality of the final product of synthetic rutile in terms of $\mathrm{TiO}_{2}$ content produced from ilmenite minerals is independent of the initial $\mathrm{TiO}_{2}$ content of the mineral. However, the presence of appreciable quantity of iron oxide in lean ore produce very large quantity of iron oxide during rusting and hence, the viability of chemical beneficiation of the same to synthetic rutile is largely dependent on subsequent iron oxide utilization as a salable byproduct.

\section{ACKNOWLEDGMENT}

The financial support by the CSIR, New Delhi (Grant no: CMM23) under the Xth Five Year Plan Net-work programme is gratefully acknowledged. We thank the Director, National Institute for Interdisciplinary Science and Technology, Trivandrum for extending the laboratory facilities.

\section{REFERENCES}

1. AMD, (2001), Exploration and Research for Atomic Minerals. Special issue on beach and inland heavy mineral sand deposits of India, Vol.13.

2. Rama Rao, B.V, (1981), Annual report for the field season 1980-81.Unpuplished AMD report.

3. Prapbhakar Rao, G, (1973), Neendakara- Kayamkulam beach placer deposit estimation of heavy mineral in mining block - I to IV,Chavara. Unpublished AMD report.

4. Prapbhakar Rao, G, (1975a), Neendakara- Kayamkulamdeposit, Quilon district, Kerala. Heavy mineral reserve in block - II (Panmana) of KMML Ltd. Unpublished AMD report. 
5. Ramachandran, M, (1976a). Neendakara- Kayamkulamdeposit, Quilon district, Kerala. Heavy mineral reserve in block - I (Thekkumbhagam) of KMML Ltd. Unpublished AMD report.

6. Rama Rao, B.V, (1983), Report on the investigations carried out in chavara area, Quilon district, Kerala (IRE Ltd). Unpublished AMD report.

7. Nair NJK, Reghunathan Pillai K, Nalina Kumar S and Suresh Babu DS., (1987), Environmental geomorphic Atlas, Kerala Coastal Zone, Fine Report submitted to Department of Environment,Govt.of India, 113pp.

8. Krishnan S, Viswanathan G, and Balachandran K, (2001), Heavy mineral sand deposits of kerala, Exploration Research for Atomic Minerals, Vol.13, pp.111-146.

9. Jelks Barksdale, (1966), Titanium its occurrence, chemistry and technology, The Ronald Press Company, New York.

10. Agrawal B .C and S P Jain, (1976), A Textbook of metallurgical analysis, Khanna publishers, Delhi.

11. Pryor W.A. and Hester N.C. (1969), X-ray diffraction analysis of heavy minerals, J.Sede. Petrol., Vol. 39, pp. 1384-1389.

12. Mohan Das P.N, Damodaran A.D, Bhat K.H., S.Velusamy, and S.Sasibhooshanan, (1996), An Improved process for the production of high grade synthetic rutile, Indian Patent No.196947.

13. Forst M.T, Grey I.E, Harrowfield IR and Mason K, (1983), The dependence of alumina and silica contents on the alteration of weathered ilmenites from western Australia, Mineral.Mag; 47, pp.201-208.

14. Mallik, T. K., V.Vasudevan, P. A.Verghese, and T.Machado. (1987), The Black sand placer deposits of Kerala beach, southwest India. Marine Geology 77: p129-150.

15. Murthy, M.V.N., (1969), Zircon. Geological survey of India, Miscellaneous publication 9,236PP. 